\title{
Study on Liquefaction Resistance of Pile Group by Shaking Table Test
}

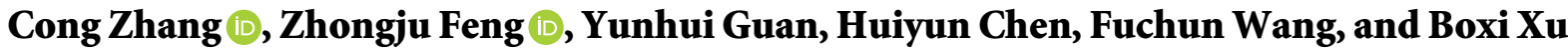

School of Highway, Chang'an University, Xi'an 710064, China

Correspondence should be addressed to Cong Zhang; zhangcong@chd.edu.cn

Received 2 November 2021; Accepted 24 December 2021; Published 25 January 2022

Academic Editor: Meng Gao

Copyright (C) 2022 Cong Zhang et al. This is an open access article distributed under the Creative Commons Attribution License, which permits unrestricted use, distribution, and reproduction in any medium, provided the original work is properly cited.

\begin{abstract}
This study investigated the antiliquefaction property of the pile group. It is shown in the pore pressure ratio, pile acceleration, and bending moment response of saturated silt fine sand. The response law of pile acceleration and bending moment during liquefaction development is proved. The results show that liquefaction occurs in single piles, four piles, and six piles under the action of $0.35 \mathrm{~g}$ seismic wave. But the time of liquefaction is different. There is an obvious difference in the response of pile acceleration and bending moment during liquefaction. Liquefaction in the saturated silt fine sand develops from shallow to deep. The complete liquefaction of six piles takes the longest time, while the single pile takes the shortest time, and the average delay was $8.82 \mathrm{~s}$. With the increase of the number of piles, there are some differences in pile acceleration, magnification factor, and pile bending moment, which are mainly reflected in time. The peak acceleration appearance of six piles was $3.08 \mathrm{~s}$ later than that of the single pile on average. The maximum bending moment appearance of six piles was $1.96 \mathrm{~s}$ later than that of the single pile on average. The acceleration and bending moment of the pile begins to attenuate when the pore pressure ratio increases. It shows that the saturated silt fine sand has softening and damping effect before liquefaction. In summary, the antiliquefaction performance of the pile group is better than that of a single pile. In the seismic design of pile foundation in liquefied soil, the antiliquefaction performance of the pile group is better.
\end{abstract}

\section{Introduction}

According to the results of earthquake damage investigation, the seismic performance of pile foundation is better than other types of foundation. Bridge structure with pile foundation has relatively light seismic damage and the seismic performance is good. Sand liquefaction induced by earthquakes is one of the important causes of earthquake damage to the pile foundations [1-4]. Therefore, research on antiliquefaction treatment measures of pile foundation has become an important direction and hot topic in geotechnical engineering. Through the research on the antiliquefaction performance of pile foundation, it is found that the antiliquefaction technical measures can be divided into two kinds [5-8]. One is to treat the soil around the pile to completely lose the liquefaction condition, which has a large amount of work and large limitations. Another is that liquefaction is allowed without changing the properties of the soil around piles, which optimizes the design of the pile foundation to improve the antiliquefaction performance of the pile foundation itself.

At present, scholars have carried out a series of researches on the pile-soil dynamic interaction in liquefied sites under earthquake. In terms of theoretical analysis, Rahmani et al. [9] used the fully coupled three-dimensional dynamic analysis to study the dynamic response of a single pile in liquefied ground. Wu et al. [10] used Laplace transform technique and variable separation technique to obtain the analytical solution of the vertical dynamic response of pile in layered transversely isotropic soil. As per Deng et al. [11], based on the Euler-Bernoulli rod theory, the pile-soil control equation under the action of arbitrary harmonics is established. Harada et al. [12] proposed that the compaction sand pile method is an effective measure for antiliquefaction of sand foundation and introduced other antiliquefaction methods derived from it. Zhou et al. [13] 
calculated the dynamic response law of pile groups through pile-soil dynamic interaction factors and concluded that the flexibility ratio and pile spacing of pile groups have a great influence on the dynamic response of piles. Lu et al. [14] established a layered porous elastic half-space pile group dynamic analysis numerical model based on the Biot theory and studied the influence of factors such as pile group spacing and pile length on the foundation vibration isolation effect. Hussein et al. [15] studied the vertical dynamic response characteristics of pile foundation in liquefied and nonliquefied sites. In terms of model tests, Feng et al. [16] and others studied the dynamic response of rock-socketed pile foundations under strong earthquakes and the influence of sand liquefaction on the dynamic response of bridge pile foundations and proposed a method of burying the pile foundation with saturated silt liquefaction judging method based on depth, seismic intensity, and pore pressure ratio. $\mathrm{Xu}$ et al. [17] researched pile group dynamic responses characteristics in liquefied and nonliquefied sites by shake table tests. Bahmanpour et al. [18] studied the mitigation effect of underground columns on soil liquefaction in shaking table experiments. Rajeswari et al. [19] studied the inclined pile group dynamic responses in laterally spreading ground. Sawamura et al. [20] studied the seismic performance of liquefied pile group foundation through the centrifugal model test. Bao et al. [21] studied the seismic enhancement effect of pile group foundation with partial ground improvement method by the shaking table test and numerical simulation. Chiou et al. [22] carried out the liquefaction dynamic response characteristics of single pile with different stiffness through shaking table test. In the aspect of numerical simulation, Wang et al. [23] applied the unified plasticity model for large postliquefaction shear deformation of sand to the three-dimensional finite element model of liquefied foundation piles. Saeedi et al. [24] established the finite element difference model of underground rock-socketed single pile in seismic liquefaction field by FLAC and studied the dynamic response of pile. Mokhtar et al. [25] study the seismic performance of piles penetrated into liquefiable sandy soil by the 3D finite element program. Janalizadeh et al. [26] established a three-dimensional finite element model by open-source computer-traditional platform OpenSees and studied the influence of soil layer delamination, movement force, and inertia force on the dynamic response of pile. The above research is limited to the dynamic response characteristics of pile group foundation in liquefaction site. The antiliquefaction performance of the pile group is limited to qualitative analysis and no quantitative comparison with the single pile. There are few studies on the micromanifestation of pile group liquefaction resistance superior to single pile foundation under earthquake.

In this shaking table test, three working conditions of the single pile, four piles, and six piles were designed. Time history response of pore pressure ratio, pile acceleration, and pile bending moment in saturated silt fine sand, and their relationships were studied. The differences in antiliquefaction performance under three working conditions were emphatically discussed. It provides theoretical support and design guidance for antiliquefaction research of pile foundations.

\section{Engineering Background}

The Haiwen Bridge (formerly Puqian Bridge) in Hainan Province, China, is located in a strong earthquake zone. The seismic fortification intensity of the Haiwen Bridge is VIII degree. The basic design acceleration of ground motion is $0.35 \mathrm{~g}$, which far exceeds the design value of fortification intensity $(0.20 \mathrm{~g})$ in Article 3.1.4 of the "Specification of Seismic Design for Highway Engineering (JTGB02-2013)" [27] and exceeds the standard value of penetration hammer of liquefaction criterion in Article 4.4.2. The liquefaction of sand soil is serious, so it is urgent to study the antiliquefaction performance of pile foundation. The Haiwen Bridge adopts pile group, among which 55\# pile foundations are 4 friction piles with $2 \mathrm{~m}$ diameter and $35 \mathrm{~m}$ length, as shown in Figure 1. The pile foundation passes through clay $5 \mathrm{~m}$, fine sand $8 \mathrm{~m}$, pebble soil $25 \mathrm{~m}$ from top to bottom. The specific gravity of the fine sand is 2.67 , the saturation gravity is $22.19 \mathrm{kN} / \mathrm{m}^{3}$, the void ratio is 0.83 , the plasticity index is 19.3 , and the liquidity index is 0.32 .

\section{Materials and Methods}

3.1. Parameters of the Shaking Table. This shaking table model test relies on the three-dimensional six-degree-offreedom shaking table in the Earthquake Engineering and Engineering Vibration Laboratory of the Institute of Engineering Mechanics, China Earthquake Administration. The size of the table is $5.0 \mathrm{~m} \times 5.0 \mathrm{~m}$. The size of the laminated shear model box is $3.7 m \times 2.8 \mathrm{~m} \times 2.0 \mathrm{~m}$, as shown in Figure 2. The maximum load of the shaking table is $30 \mathrm{t}$, the frequency is $0.5 \mathrm{~Hz} \sim 50 \mathrm{~Hz}$, and the maximum horizontal acceleration amplitude and maximum displacement amplitude are $1.0 \mathrm{~g}$ and $80 \mathrm{~mm}$, respectively. After comprehensive comparison of the advantages and disadvantages of rigid model box, cylindrical, flexible model box, and laminated shear model box, the laminated shear model box is selected to reduce the boundary effect. The specific parameters and boundary effect verification of the laminated shear model box has been described in detail in reference [28]. When the length of the model box is more than $2 \mathrm{~m}$ and the width is more than $1.5 \mathrm{~m}$, the natural frequency error is less than 5\% [29]. A rubber pad with a thickness of $1 \mathrm{~cm}$ is set on the inner wall of the model box to prevent soil or water from overflowing during vibration.

3.2. Similar Relation. The geometric similarity scale is $1: 25$. According to the Bockingham $\pi$ theory, the dimensional analysis method is adopted. Considering the similarity of seismic load, the similarity ratio of each physical quantity is shown in Table 1.

3.3. Model Pile Making. C35 concrete is used as the model pile material. The model pile length is $138 \mathrm{~cm}$, the pile diameter is $8 \mathrm{~cm}$, and the pile spacing of the four piles and six 


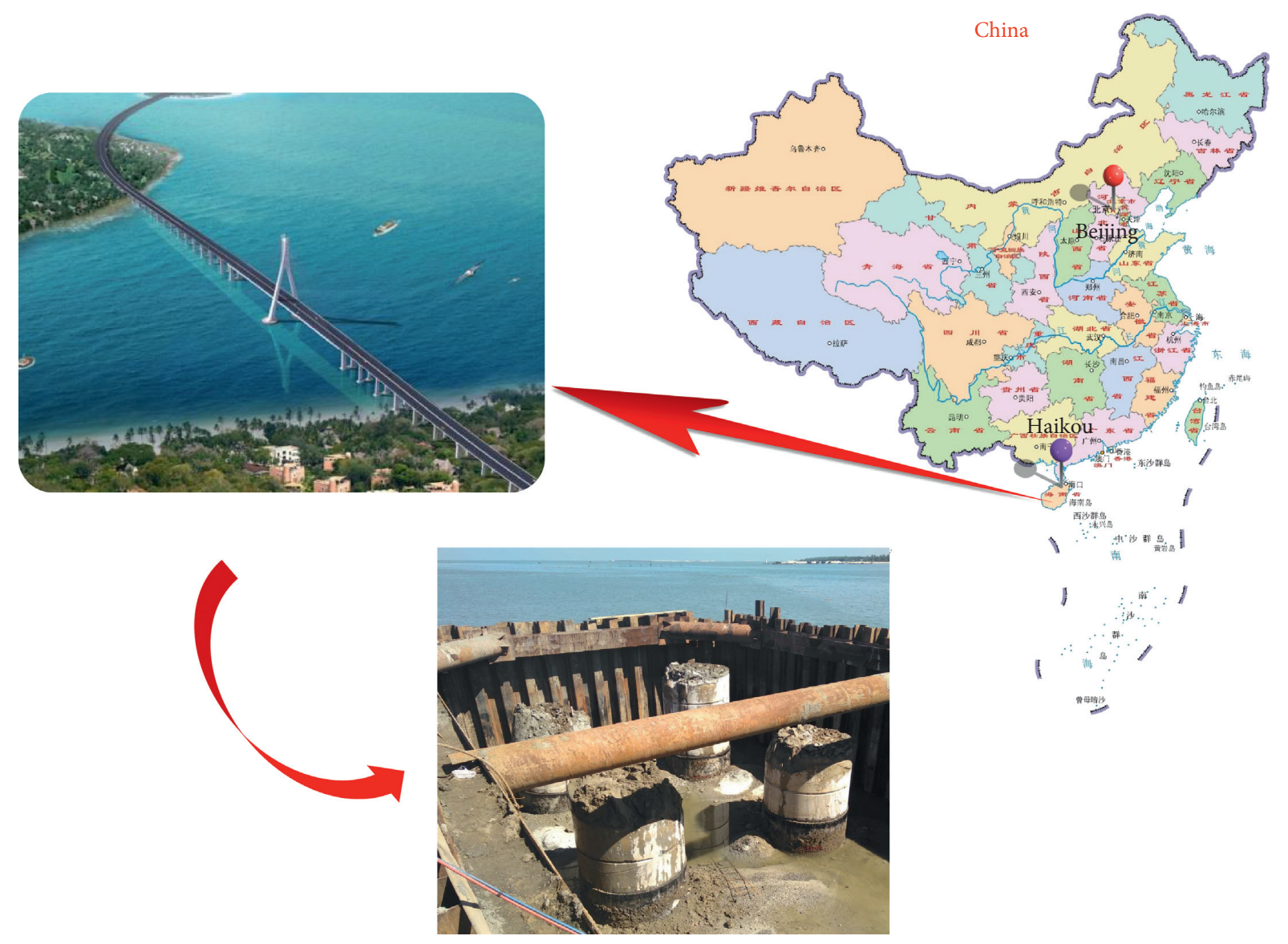

Figure 1: Pile foundation 55\#.
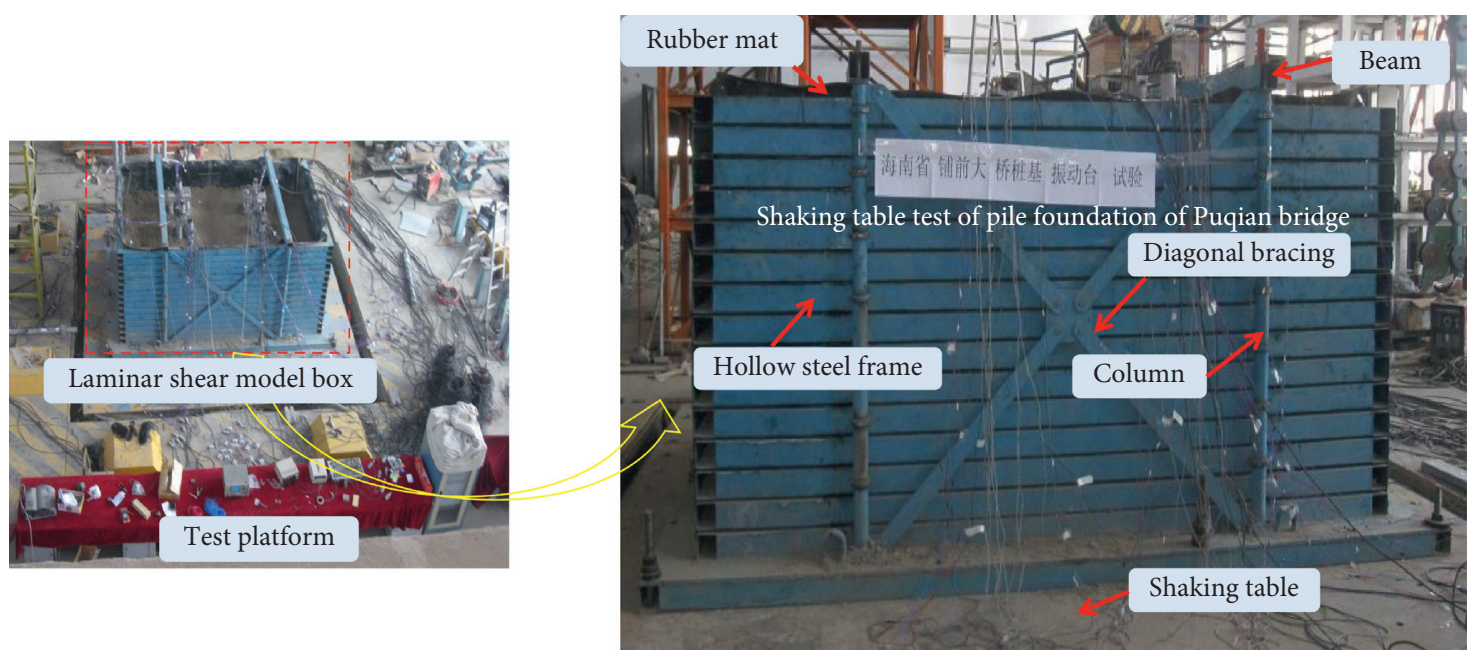

Figure 2: Laminated shear model box. 
TABLE 1: Similarity constants of shaking table model test.

\begin{tabular}{lcc}
\hline Parameters & $\begin{array}{c}\text { Similarity relation } \\
\text { (model/prototype) }\end{array}$ & $\begin{array}{c}\text { Similarity constant } \\
\text { (model/prototype) }\end{array}$ \\
\hline Acceleration, $a$ & 1 & 1 \\
Wire size, $l$ & $C_{1}$ & $1 / 25$ \\
Linear displacement, $\delta$ & $C_{1}$ & $1 / 25$ \\
Frequency, $\omega$ & $\mathrm{C}_{1}^{-1 / 2}$ & 5 \\
Elastic modulus, $E$ & 1 & 1 \\
Stress, $\sigma$ & 1 & 1 \\
Strain, $\varepsilon$ & 1 & 1 \\
Poisson's ratio, $\mu$ & 1 & 1 \\
Internal friction angle, & 1 & 1 \\
$\varphi$ & 1 & 1 \\
Cohesion, $c$ & & \\
\hline
\end{tabular}

piles is $14 \mathrm{~cm}$. The pile reinforcement ratio is $2.4 \%$, as shown in Figure 3. According to a similar relationship and formula (1), the artificial masses of $50 \mathrm{~kg}, 200 \mathrm{~kg}$, and $300 \mathrm{~kg}$ for a single pile, four piles, and six piles top are, respectively, determined [30, 31].

$$
m_{a}=C_{E} C_{l}^{2} m_{p}-m_{m}
$$

Before loading the seismic wave, input the white noise and collect the acceleration time history response of the pile. The SeismoSignal seismic wave processing software is used to obtain the Fourier spectrum. The natural frequency of the pile foundation is determined by the Fourier spectrum, as is shown in Figure 4.

3.4. Model Soil Design. The model soil is divided into clay, silt fine sand, and pebble soil. Based on the geological survey data, the soil shear wave speed is the main control index to ensure that the model soil is similar to the original soil. The process of shear wave velocity method in this test involved the following steps:

(1) An accelerometer is placed at the bottom of the custom container and loaded into the tested model soil

(2) After the model soil was compacted with a tamping hammer and recorded the compaction times, an accelerometer was placed on the surface of the model soil

(3) Knocked on the bottom of the container and captured the peak time of two accelerometers by the data acquisition system

(4) The shear wave velocity of the model soil can be calculated from the following equation, as shown in Table 2 and Figure 5(a)

$$
v=\frac{\Delta h}{\Delta t}
$$

The particle size of the pebble is $1.5 \sim 2.5 \mathrm{~cm}$, accounting for $25 \%$ of the total mass, and is mixed evenly with the fine sand. The standard sand, which is easy to liquefy, was used in the test. The overlying clay is filled after the saturated silt fine sand is fully saturated by standing water injection for $24 \mathrm{~h}$. The particle size distribution is shown in Figure 6. The moisture content of clay is measured by the drying method, and its density is measured by the ring knife method, as shown in Figure 5(b). To ensure the compactness of the soil layer, the layered tamping method is used to fill the soil layer. When filling the soil layer, use a saw blade to shave the surface of the soil layer at the interface of the soil layer to ensure good contact between the soil layers.

3.5. Sensor Layout. To eliminate the influence of the interaction between the three test conditions, the distance between each working condition is not less than $80 \mathrm{~cm}$ (10D). In the saturated silt fine sand, the pile body is embedded with uniaxial patch miniature acceleration sensor $A_{1} \sim A_{9}$, and resistive strain gauge $\mathrm{P}_{1} \sim \mathrm{P}_{18}$. The strain gauges were symmetrically arranged, and each strain gauge was provided with a compensation gauge. The pore water pressure sensors $K_{1} \sim K_{6}$ were embedded in the soil layer on the side of the pile. All sensors embedded in liquefied soil are waterproof. The surface of the test element is coated with epoxy resin. The pore water pressure sensors were wrapped in cotton to prevent the influence of soil particle displacement on it in the process of liquefaction. The wire relative displacement sensors $W_{1} \sim W_{3}$ were arranged at the pile top. This paper focuses on the interaction mechanism between pile foundation and the saturated silt fine sand, so the test element is only embedded in the saturated silt fine sand. The specific layout methods are shown in Table 3 and Figure 7.

3.6. Test Conditions. The test conditions are the comparison of the antiliquefaction performance of a single pile, four piles, and six piles. The test loading seismic wave was artificially synthesized by the China Earthquake Administration for the Hainan Haiwen Bridge with a probability of exceeding $10 \%$ in 50 years (referred to as 5010 waves), and a dynamic peak acceleration of $0.35 \mathrm{~g}$, and using SeismoSigal software to correct the baseline. The time history curve and frequency spectrum are shown in Figure 8, and the test conditions are shown in Table 4 . The shaking model test operation processes are shown in the following Figure 9. In this test, the three working conditions are tested in the same model box. The consistency is mainly reflected in the following four aspects: (1) Same soil conditions; (2) Same input seismic wave; (3) Same boundary conditions; (4) Same inertia force effect.

\section{Results and Discussion}

4.1. Experimental Phenomenon. By observing the phenomenon of the shaking table test, the model pile and the model soil produce obvious vibration under the ground motion load of $0.35 \mathrm{~g}$. The surface of foundation soil has cracks and uneven settlement. There is a lot of water and bubbles on the surface. There are a lot of water and bubbles coming out of the surface of the foundation, as 


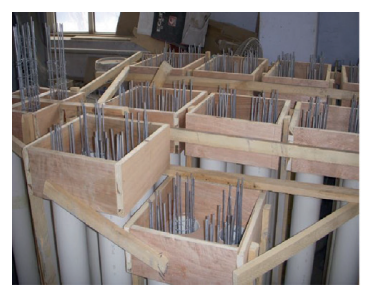

Arrangement of bars

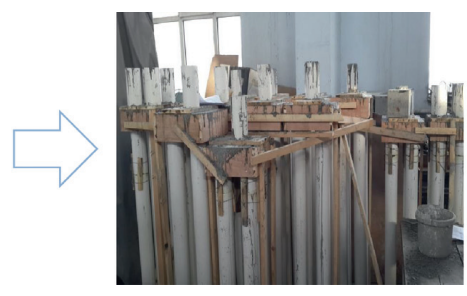

Pouring concrete

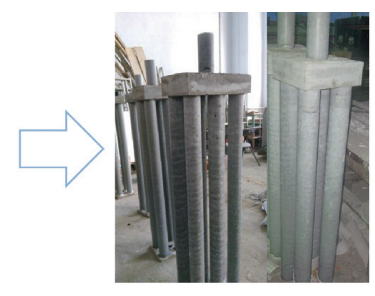

Removal of shuttering

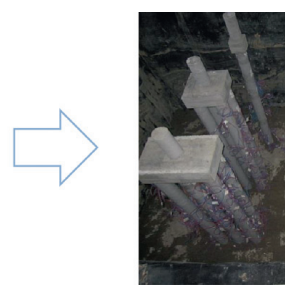

Lay out the sensor

Figure 3: Model piles.

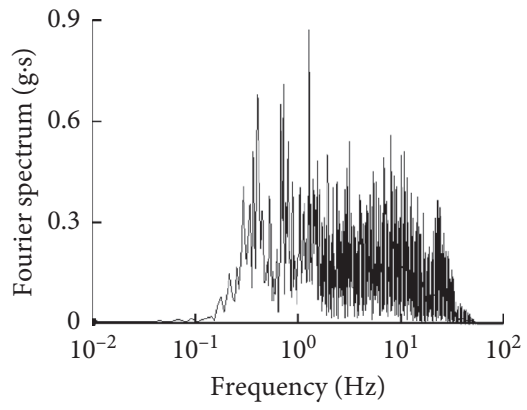

(a)

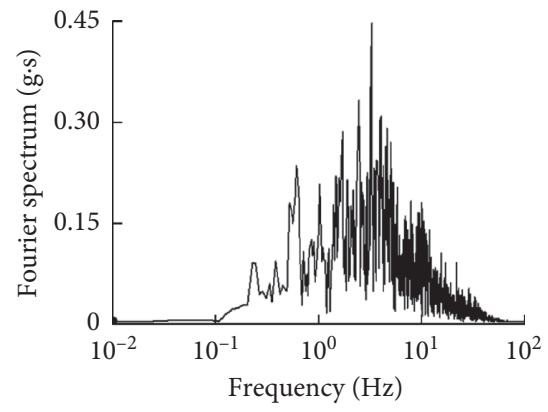

(b)

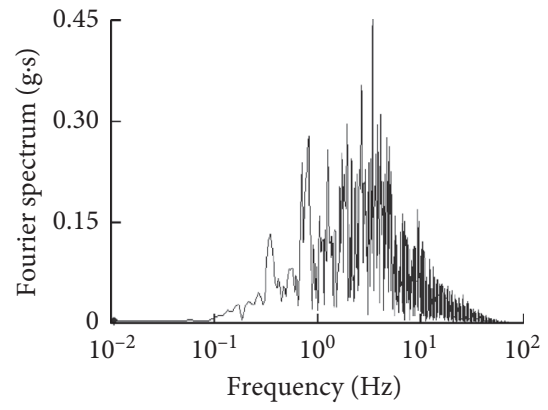

(c)

FIgURE 4: Natural frequencies of pile foundation. (a) Single-pile. (b) Four piles. (c) Six piles.

TABLE 2: Shear wave velocities of soils.

\begin{tabular}{|c|c|c|c|c|}
\hline Nam & & Clay & Saturated silty sand & Pebble soil \\
\hline \multirow{2}{*}{ Shear wave velocity/m•s ${ }^{-1}$} & Prototype & 136 & 162 & 526 \\
\hline & Model & 138 & 177 & 539 \\
\hline
\end{tabular}
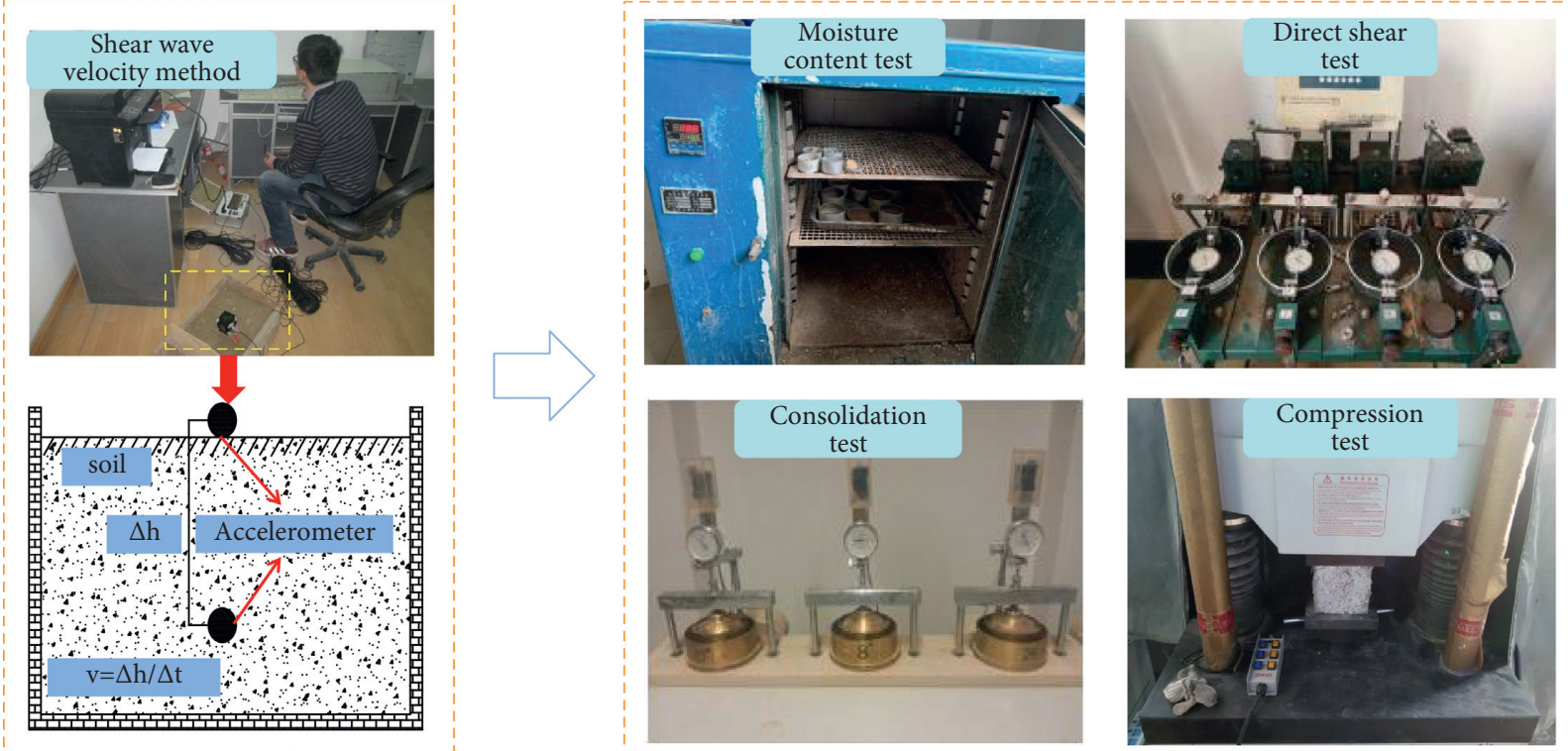

Figure 5: Physical property test. (a) Shear wave velocity. (b) Physical and mechanical test. 


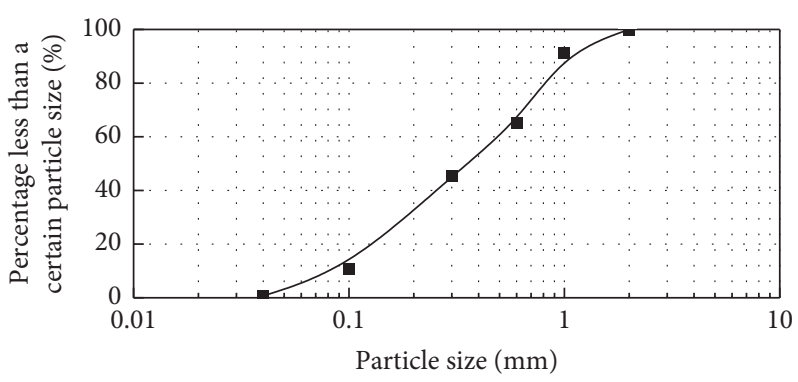

Figure 6: Particle size distribution curve of sand.

TABLE 3: Layout position of test elements.

\begin{tabular}{lcccc}
\hline Test component type & Acceleration sensor & Pore water pressure sensor & Strain gauge & Displacement sensor \\
\hline Buried location $(\mathrm{cm})$ & $26,39,52$ & 34,44 & $26,39,52$ & Pile cap \\
Quantity/number & 9 & 6 & 18 & 3 \\
\hline
\end{tabular}

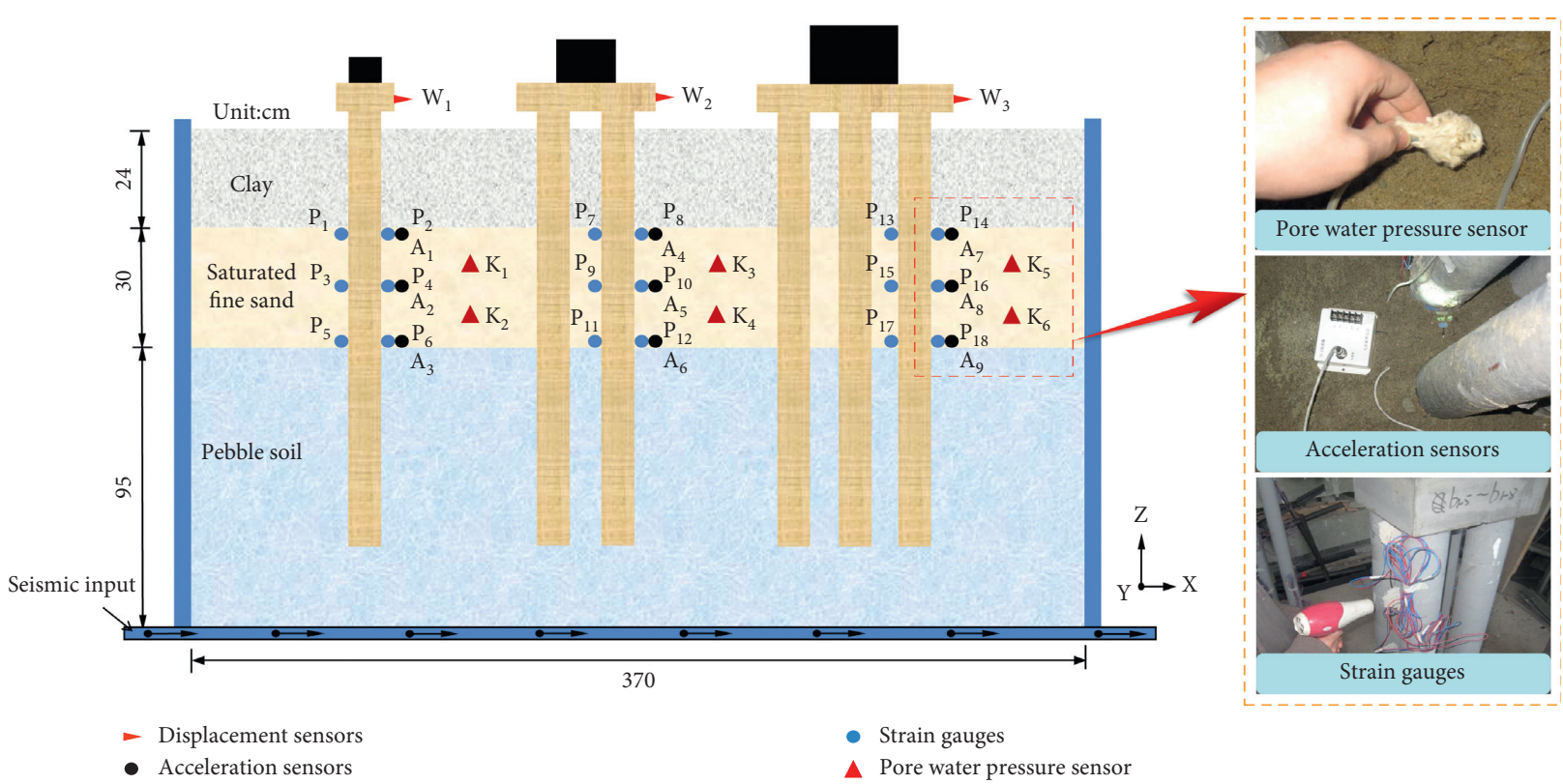

FIGURE 7: Layout of test elements.

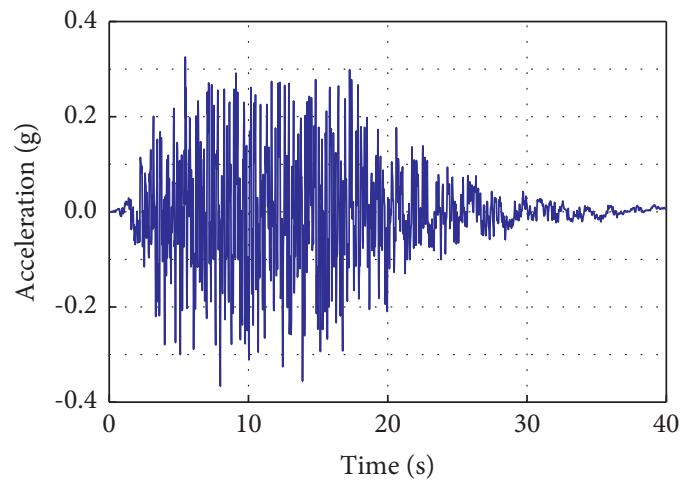

(a)

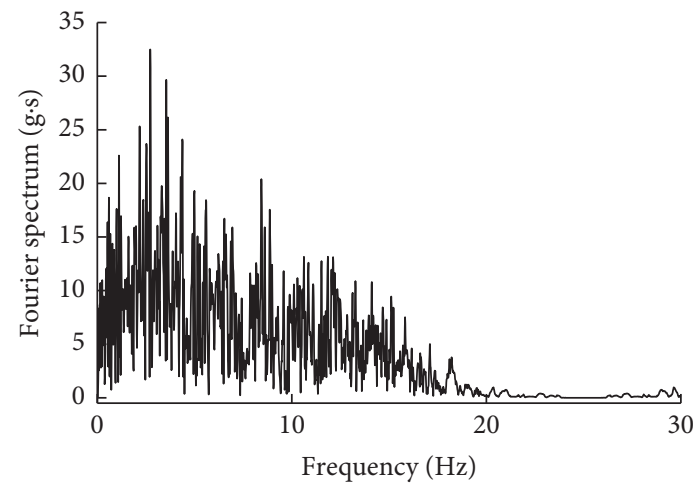

(b)

Figure 8: Time history and spectrum of seismic waves. (a) Seismic wave time history (b) Seismic frequency spectrum. 
TABle 4: Test conditions.

\begin{tabular}{lccc}
\hline Test condition & Load wave form & Acceleration amplitude $(\mathrm{g})$ & Vibration duration $(\mathrm{s})$ \\
\hline Single pile & 5010 & 0.35 & 40 \\
$\begin{array}{l}\text { Four piles } \\
\text { Six piles }\end{array}$ & & & \\
\hline
\end{tabular}
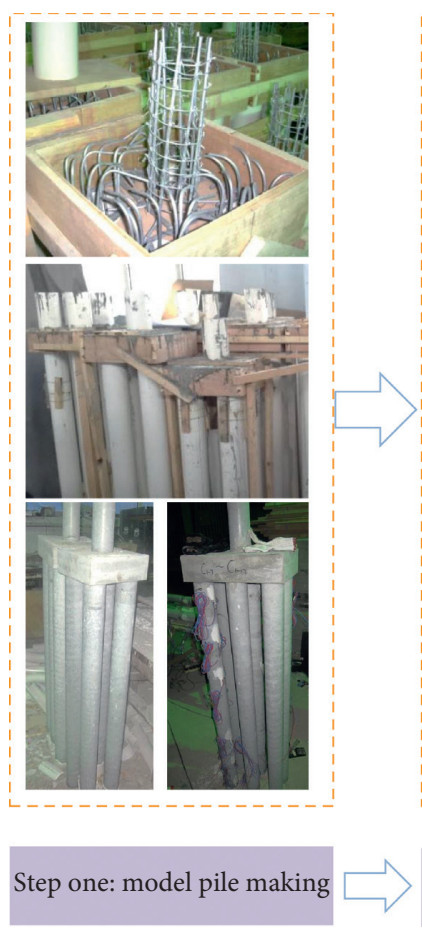
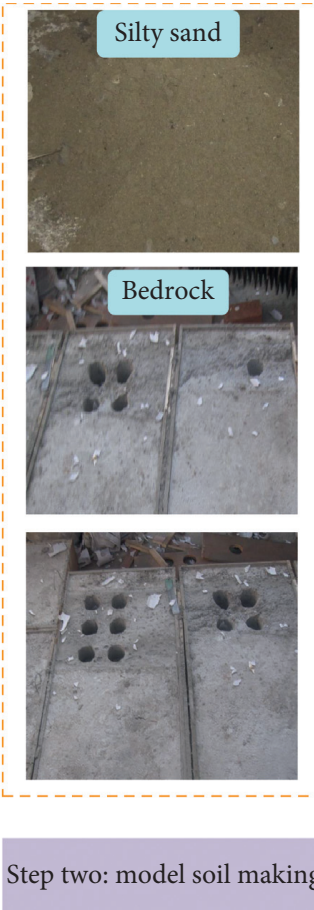
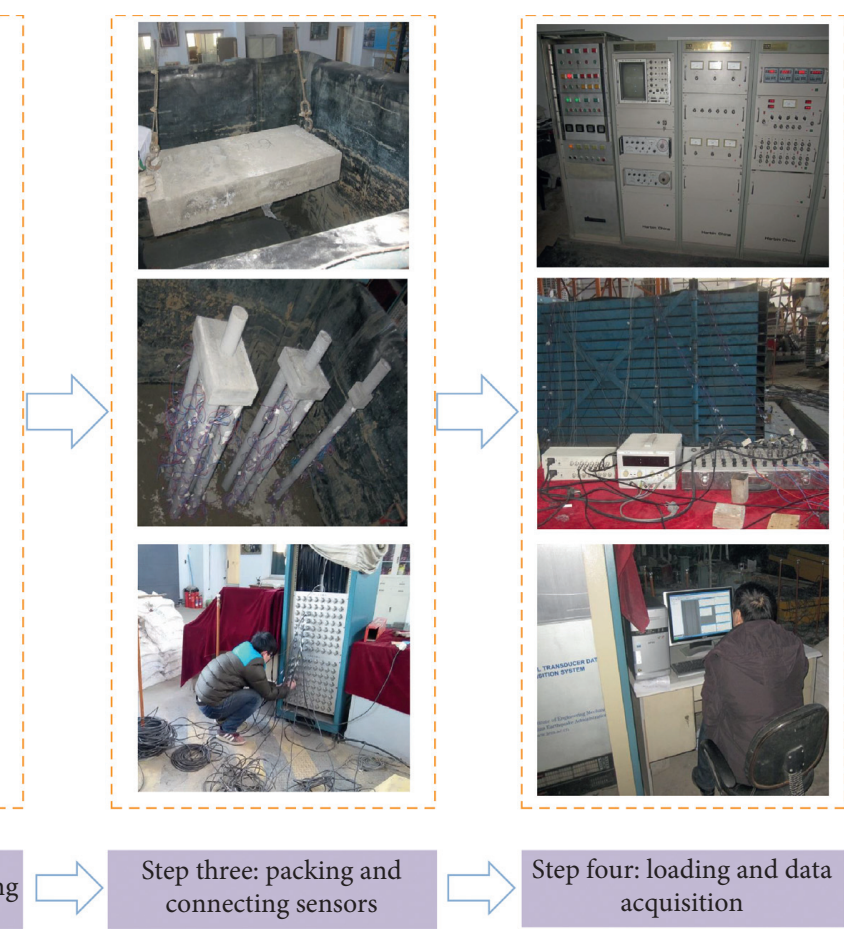

Step four: loading and data acquisition

Figure 9: Test operation process.

shown in Figure 10. At this time, liquefaction occurs in the saturated silt fine sand under three working conditions. However, the liquefaction time of six piles is clearly behind that of four piles and single pile. The soil structure is damaged and the soil particles are gradually densified by relative displacement under $0.35 \mathrm{~g}$ ground motion load. The poor permeability of the saturated silt fine sand leads to a sharp increase in pore water pressure, a decrease in effective stress, and a decrease in shear strength. Because the natural vibration frequency of a single pile, four piles, and six piles are different, the liquefaction time of saturated silt fine sand is different when the pile foundations interact with foundation soil. As the number of piles increases, the effect of pile group strengthening the foundation soil is enhanced. Under the action of ground motion, the damping of the pile-soil interaction system is enhanced, and the antiliquefaction performance of the pile group is better.

4.2. Pore Pressure Ratio. The pore pressure ratio is the ratio of pore water pressure to effective stress. The time history curve of the pore pressure ratio under three conditions is shown in Figure 11. The variations of pore pressure ratio in saturated fine sand soil of a single pile, four piles, and six piles are roughly the same. The pore pressure ratio remained near 0 at the beginning of seismic wave loading, then increased rapidly after a period of time and finally reached stability. The pore pressure ratio in the depth of saturated silt fine sand $\left(\mathrm{K}_{2}, \mathrm{~K}_{4}, \mathrm{~K}_{6}\right)$ lags behind the shallow soil layer $\left(\mathrm{K}_{1}\right.$, $\mathrm{K}_{3}, \mathrm{~K}_{5}$ ) at the time when it starts to increase and when it stabilizes, and the increase of pore pressure ratio lags behind the ground motion load. In the vibration process of saturated silt fine sand, the higher the pore pressure ratio is, the more serious the liquefaction is. Therefore, the pore pressure ratio can be used to judge the degree of soil liquefaction. When the pore pressure ratio is 0.8 , there is a large area of water spraying and sand emitting on the surface, and the saturated silt fine sand is completely liquefied. The liquefaction characteristics of saturated silt fine sand in this test can be found in reference [32]. The saturated silt fine sand produces relative displacement due to the action of shear stress. With the relative displacement of soil particles, the upward expansion of soil particles and the temporary decrease of pore water pressure appear. As shown in Figure 11, the pore pressure ratio is negative at the initial stage of liquefaction. With the further development of liquefaction, the pore pressure ratio no longer appears negative and finally tends to a stable value.

At $34 \mathrm{~cm}$ in model soil, the pore pressure ratio at measuring points $\mathrm{K}_{1}, \mathrm{~K}_{3}$, and $\mathrm{K}_{5}$ starts to increase at $9.13 \mathrm{~s}$, $13.13 \mathrm{~s}$, and $18.03 \mathrm{~s}$. The pore pressure ratio stabilizes at 


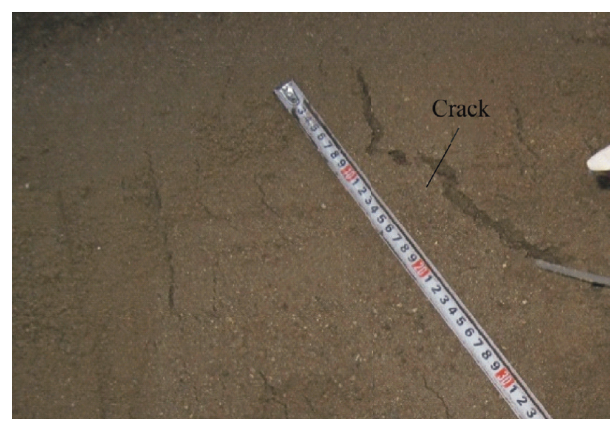

(a)

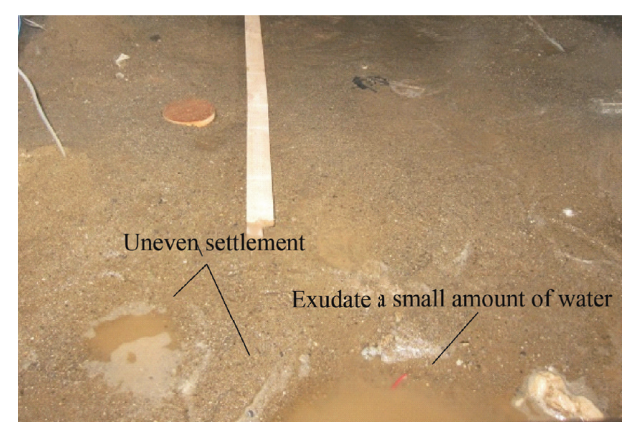

(b)

Figure 10: Fine sand liquefaction. (a) Crack. (b) Settlement and precipitation.

$21.45 \mathrm{~s}, 25.45 \mathrm{~s}$, and $30.27 \mathrm{~s}$. The development time of the pore pressure ratio is $12.32 \mathrm{~s}, 12.32 \mathrm{~s}$, and $12.24 \mathrm{~s}$, respectively. At $44 \mathrm{~cm}$, the pore pressure ratio of $\mathrm{K}_{2}, \mathrm{~K}_{4}$, and $\mathrm{K}_{6}$ start to increase at $10.01 \mathrm{~s}, 14.41 \mathrm{~s}$, and $19.01 \mathrm{~s}$. The pore pressure ratio stabilizes at $22.43 \mathrm{~s}, 26.85 \mathrm{~s}$, and $31.26 \mathrm{~s}$. The development time of the pore pressure ratio is $12.42 \mathrm{~s}$, $12.44 \mathrm{~s}$, and $12.25 \mathrm{~s}$, respectively. The start increasing time of pore pressure ratio at $\mathrm{K}_{5}$ is $4.90 \mathrm{~s}$ and $8.90 \mathrm{~s}$ later than that at $\mathrm{K}_{3}$ and $\mathrm{K}_{1}$. And the start increasing time of pore pressure ratio at $K_{6}$ is $4.60 \mathrm{~s}$ and $9.00 \mathrm{~s}$ later than that at $\mathrm{K}_{4}$ and $\mathrm{K}_{2}$, respectively. The stable time of pore pressure ratio at $\mathrm{K}_{5}$ is $4.82 \mathrm{~s}$ and $8.82 \mathrm{~s}$ later than that at $\mathrm{K}_{3}$ and $\mathrm{K}_{1}$. The stable time of pore pressure ratio at $\mathrm{K}_{6}$ is $4.41 \mathrm{~s}$ and $8.83 \mathrm{~s}$ later than that at $\mathrm{K}_{4}$ and $\mathrm{K}_{2}$, respectively. The stable time of pore pressure ratio in six piles is $4.62 \mathrm{~s}$ later than four piles on average. And the stable time of pore pressure ratio in four piles is $4.21 \mathrm{~s}$ later than the single pile average. The change of pile foundation type has little influence on the development time of the pore pressure ratio. The results show that the antiliquefaction performance of the pile group is mainly reflected at the moment when the pore pressure ratio starts to increase and becomes stable. As the increase of the pile number, the reinforcement effect of pile foundation on soil becomes more significant under the ground motion load. The permeability of soil around piles is affected, which weakens the growth rate of pore water pressure. At the initial stage of pore pressure ratio growth, the influence of seismic waves on pile group foundation lags behind, thus delaying the occurrence time of liquefaction.

4.3. Acceleration. The acceleration time history curve is shown in Figure 12. The amplitude of acceleration remains 0 at $0 \sim 2 \mathrm{~s}$, and then increases gradually. The maximum acceleration appears before the pore pressure ratio reaches a stable value, and its rule is consistent with the time history curve of the input seismic wave. With the decrease of soil depth, the amplitude of acceleration time history response increases. The acceleration of measuring point $A_{1}$ is the largest, which is $5.45 \mathrm{~m} \cdot \mathrm{s}-2$. At $26 \mathrm{~cm}$ in soil, the maximum accelerations at $A_{1}, A_{4}$, and $A_{7}$ are $5.45 \mathrm{~m} \mathrm{~s}^{-2}, 5.36 \mathrm{~m} \mathrm{~s}^{-2}$, $5.25 \mathrm{~m} \mathrm{~s}^{-2}$, which appear at $8.37 \mathrm{~s}, 10.86 \mathrm{~s}$, and $12.42 \mathrm{~s}$, respectively. At $39 \mathrm{~cm}$, the maximum accelerations at $A_{2}, A_{5}$, and $A_{6}$ are $4.57 \mathrm{~m} \mathrm{~s}^{-2}, 4.44 \mathrm{~m} \mathrm{~s}^{-2}, 4.33 \mathrm{~m} \mathrm{~s}^{-2}$, appearing at
$10.59 \mathrm{~s}, 11.52 \mathrm{~s}, 12.62 \mathrm{~s}$, respectively. At $52 \mathrm{~cm}$, the maximum accelerations at $A_{3}, A_{6}$, and $A_{9}$ are $3.60 \mathrm{~m} \mathrm{~s}^{-2}, 3.45 \mathrm{~m} \mathrm{~s}^{-2}$, $3.38 \mathrm{~m} \mathrm{~s}^{-2}$, occurring at $9.88 \mathrm{~s}, 11.40 \mathrm{~s}, 13.03 \mathrm{~s}$, respectively. At 26,39 , and $52 \mathrm{~cm}$ in soil, the maximum acceleration of six piles is less than that of four piles and a single pile, which lag behind the four piles by $1.56 \mathrm{~s}, 1.10 \mathrm{~s}$, and $1.63 \mathrm{~s}$ severally. And the four piles are $2.49 \mathrm{~s}, 0.93 \mathrm{~s}$, and $1.52 \mathrm{~s}$ later than a single pile, respectively. In the soil liquefaction process, the reinforcement effect of the pile group is more conspicuous with the increase of pile number. The soil constraint around the pile is enhanced and the antiliquefaction effect is significant.

Combined with the time history response of the pore pressure ratio, it can be known that the acceleration attenuation decay as the pore pressure ratio increases. The reason is that the development of pore water pressure plays a decisive role in pile acceleration. The saturated silt fine sand liquefaction directly results in the attenuation of acceleration. With the pile number increasing, the reinforcement range of soil by pile increases. It weakens the transmission ability of seismic waves and suppresses the growth rate of pore pressure ratio in saturated silt fine sand, which has a softening and damping effect before complete liquefaction. The antiliquefaction performance of six piles is better than that of four piles and a single pile.

The ratio of maximum acceleration to the input seismic wave acceleration peak is defined as the acceleration amplification factor, which can reflect the soil amplification effect to the input seismic wave. The acceleration amplification factor is shown in Figure 13. Under the same depth, the acceleration amplification factor of six piles is smaller than that of four piles and single pile. With the increase of pile number, the effect of soil reinforcement is more obvious, and the soil around pile can provide more resistance. Pilesoil structure system can keep its original properties for a long time under earthquake.

4.4. Bending Moment. The historical curve of pile bending moment is shown in Figure 14. The bending moment time history response is maintained near 0 when the ground motion load begins. After a period of time, the amplitude increases. After reaching the maximum value, the amplitude gradually decreases. The moment time history response lags 


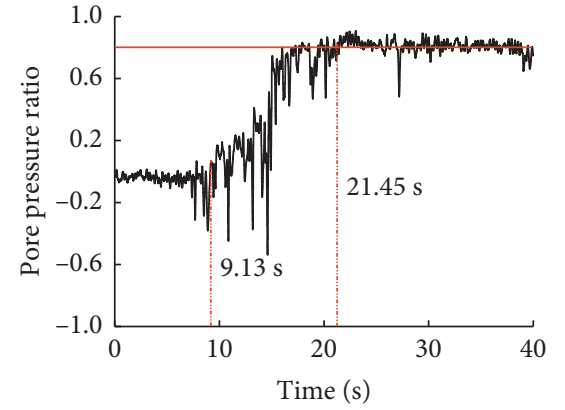

(a)

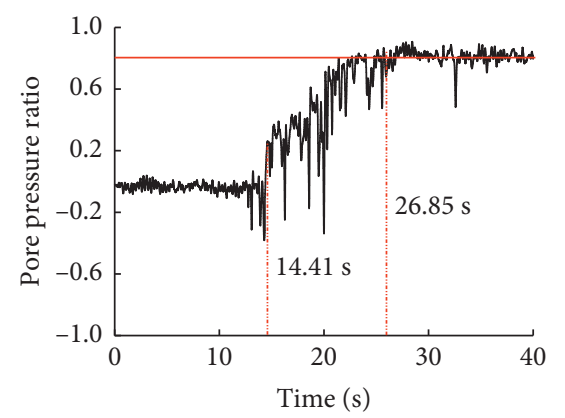

(d)

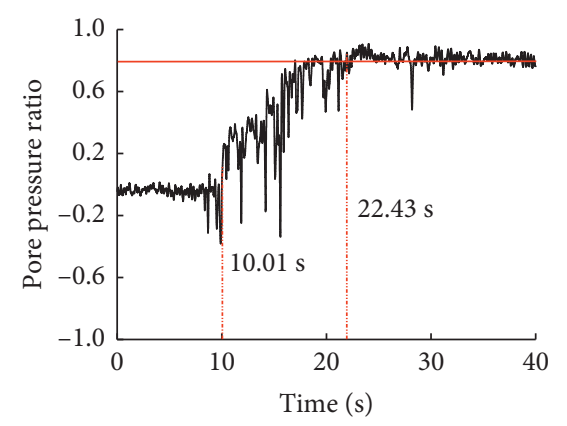

(b)

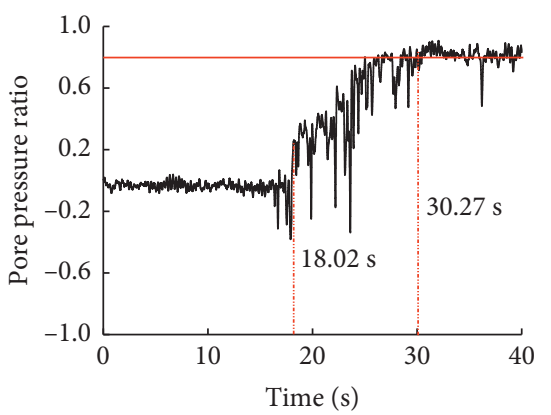

(e)

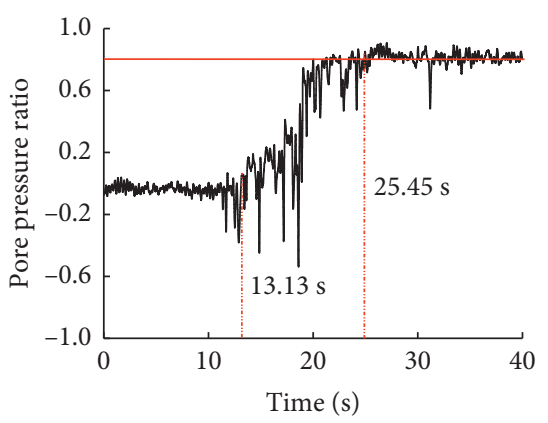

(c)

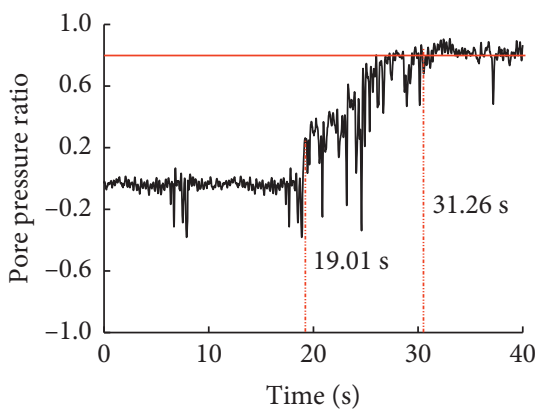

(f)

Figure 11: Pore pressure ratio time history curves. (a) $K_{1}$. (b) $K_{2}$. (c) $K_{3}$. (d) $K_{4}$. (e) $K_{5}$. (f) $K_{6}$.

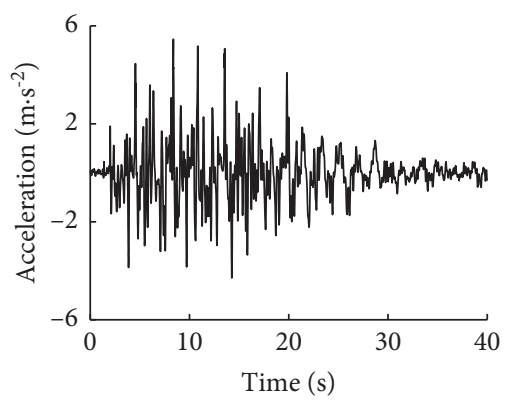

(a)

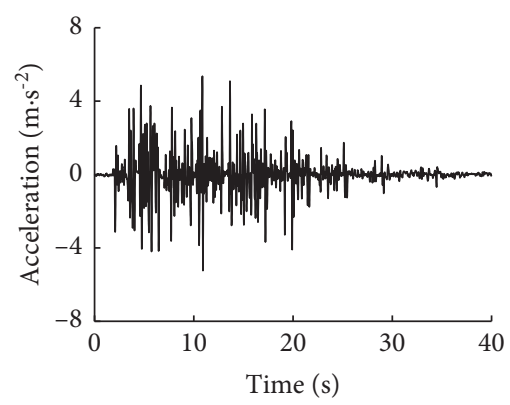

(d)

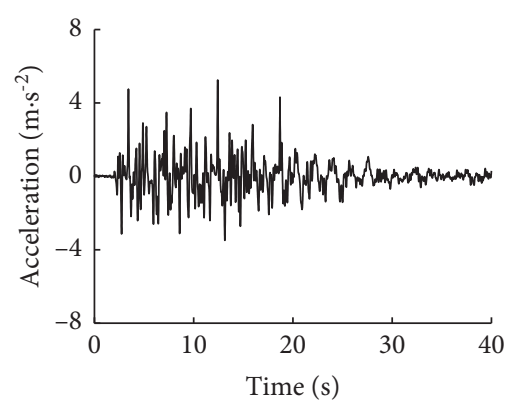

(g)

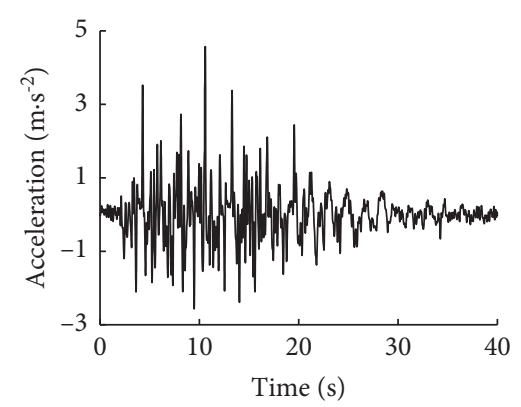

(b)

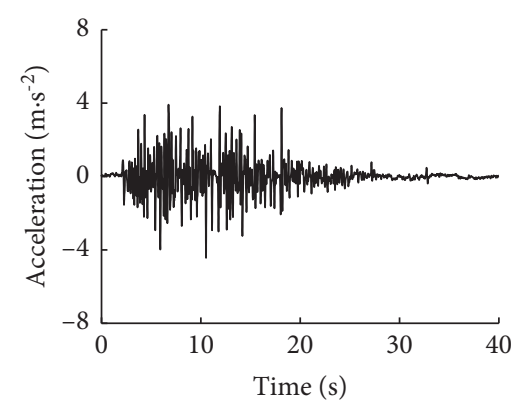

(e)

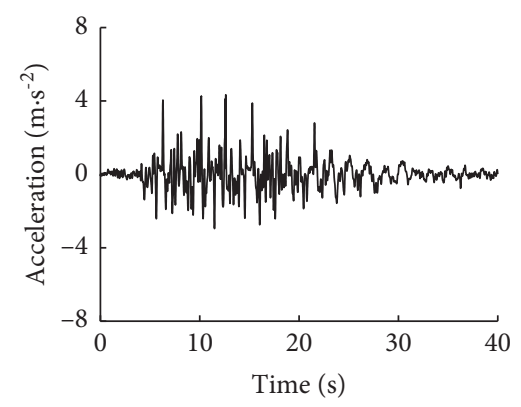

(h)

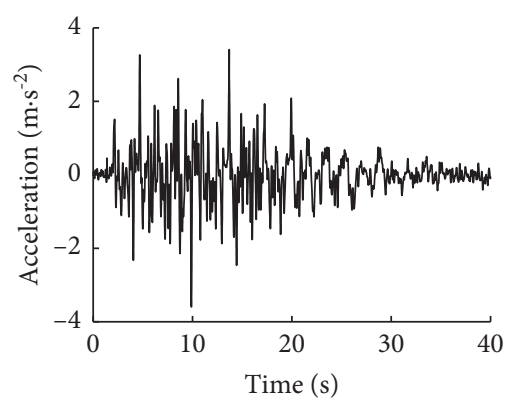

(c)

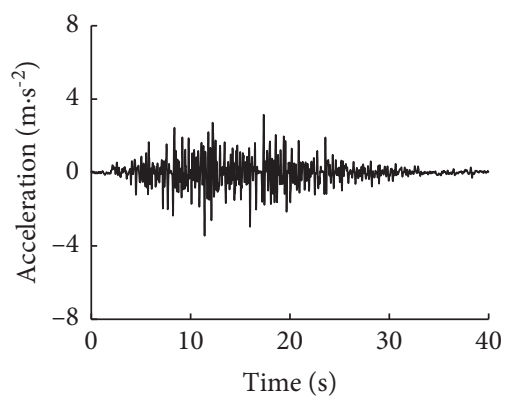

(f)

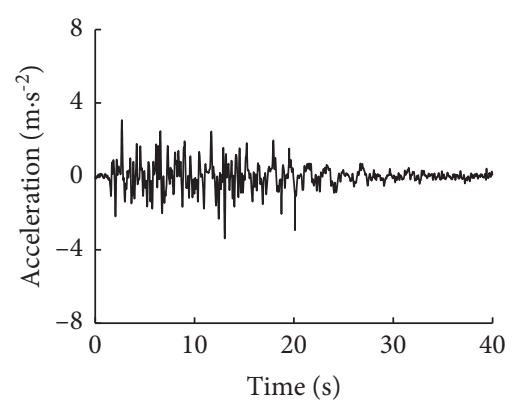

(i)

Figure 12: Acceleration time history curves. (a) $A_{1}$. (b) $A_{2}$. (c) $A_{3}$. (d) $A_{4}$. (e) $A_{5}$. (f) $A_{6} \cdot(g) A_{7}$ (h) $A_{8}$. (i) $A_{9}$. 


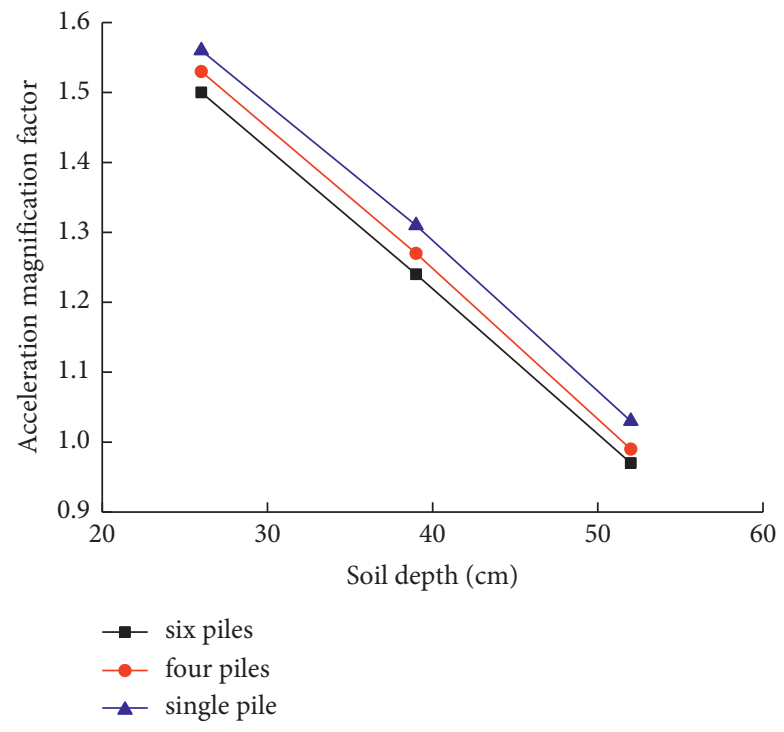

FIgURE 13: Acceleration amplification factor.

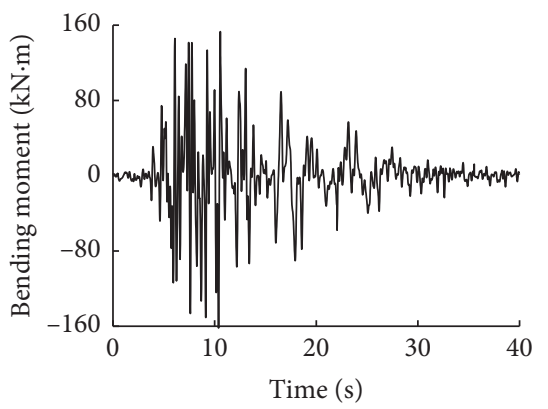

(a)

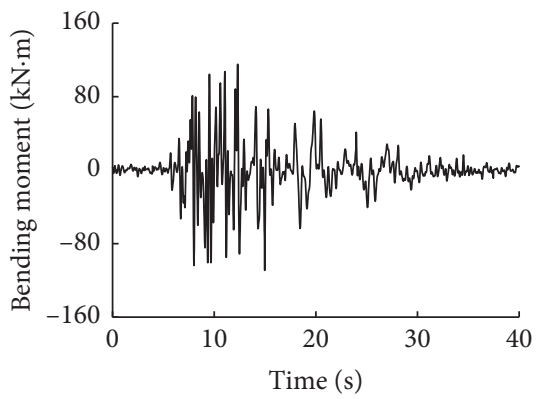

(d)

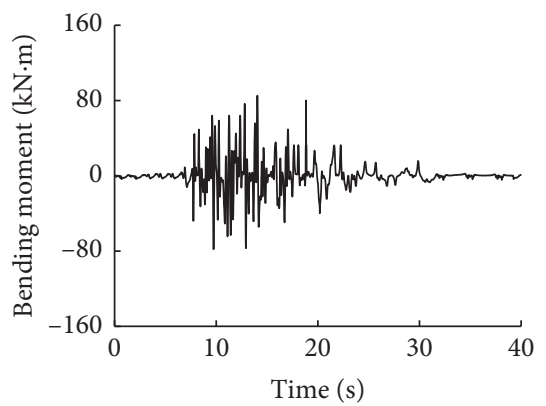

(g)

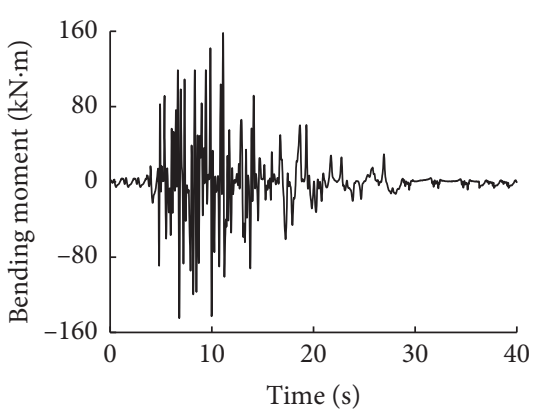

(b)

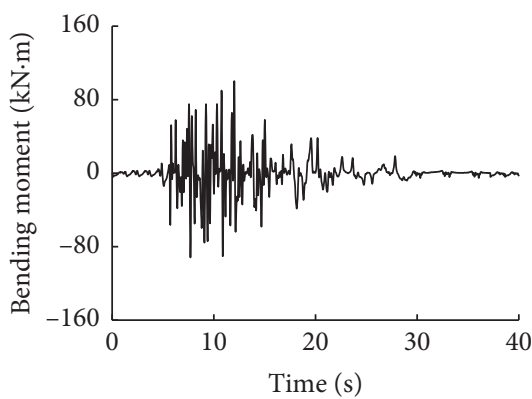

(e)

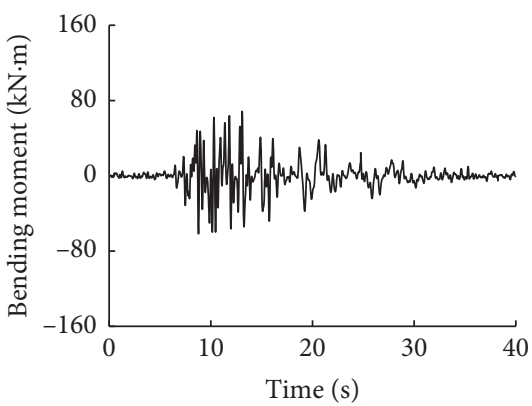

(h)

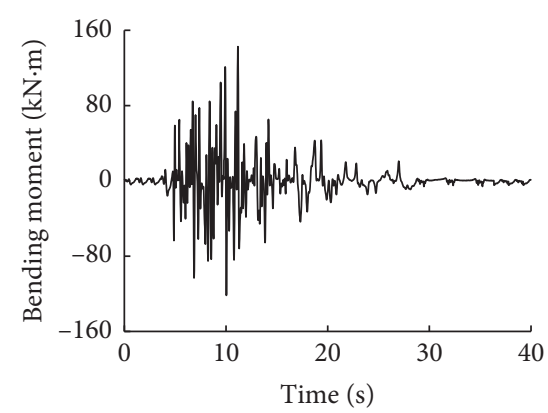

(c)

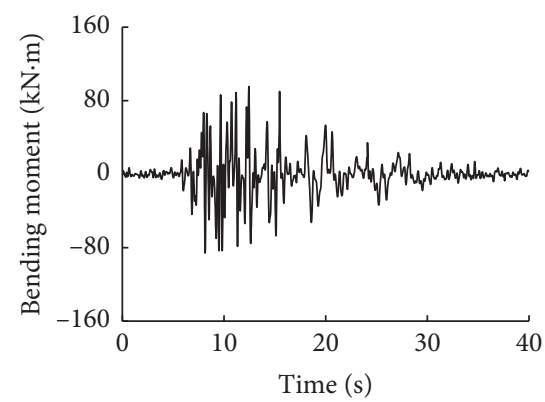

(f)

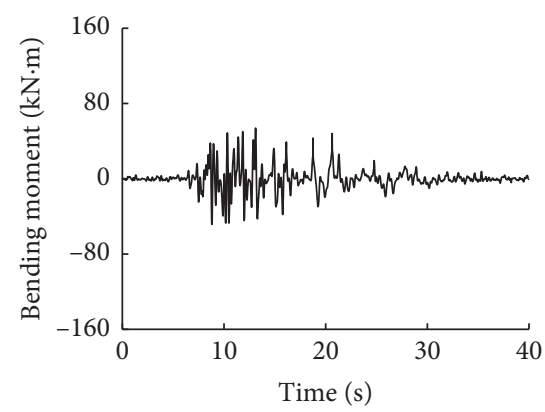

(i)

Figure 14: Bending moment time history curves. (a) $26 \mathrm{~cm}$-single pile. (b) $39 \mathrm{~cm}$-single pile. (c) $52 \mathrm{~cm}$-single pile. (d) $26 \mathrm{~cm}$-four piles. (e) $39 \mathrm{~cm}$-four piles. (f) $52 \mathrm{~cm}$-four piles. (g) $26 \mathrm{~cm}$-six piles. (h) $39 \mathrm{~cm}$-six piles. (i) $52 \mathrm{~cm}$-six piles. 
behind the seismic wave time history. Under the same soil depth, the maximum bending moment of six piles is smaller than that of four piles and a single pile, whose occurrence lags the four piles and single pile. At $26 \mathrm{~cm}$ in model soil, the maximum bending moments of the single pile, four piles, and six piles are $161.8 \mathrm{kN} \cdot \mathrm{m}, 115.2 \mathrm{kN} \cdot \mathrm{m}, 85.3 \mathrm{kN} \cdot \mathrm{m}$, which appear at $11.12 \mathrm{~s}, 12.40 \mathrm{~s}, 13.08 \mathrm{~s}$, respectively. At $39 \mathrm{~cm}$, they are $158.2 \mathrm{kN} \cdot \mathrm{m}, 100.1 \mathrm{kN} \cdot \mathrm{m}, 68.5 \mathrm{kN} \cdot \mathrm{m}$, appearing at $11.12 \mathrm{~s}$, $12.40 \mathrm{~s}, 13.08 \mathrm{~s}$, severally. At $52 \mathrm{~cm}$, they are $142.6 \mathrm{kN} \cdot \mathrm{m}$, $95.4 \mathrm{kN} \cdot \mathrm{m}, 53.9 \mathrm{kN} \cdot \mathrm{m}$, occurring at $11.17 \mathrm{~s}, 12.44 \mathrm{~s}$, and $13.10 \mathrm{~s}$, respectively. Under the ground motion load, the maximum bending moment of six piles is $25.95 \%, 31.57 \%$, and $43.50 \%$ lower than that of four piles at $26 \mathrm{~cm}, 39 \mathrm{~cm}$, and $52 \mathrm{~cm}$ soil layer, and their occurrence lags the four piles $0.72 \mathrm{~s}, 0.68 \mathrm{~s}$, and $0.66 \mathrm{~s}$, respectively. The maximum bending moment of four piles is $28.80 \%, 36.73 \%$, and $33.10 \%$ lower than that of a single pile, and their occurrence lags single piles $1.22 \mathrm{~s}, 1.28 \mathrm{~s}$, and $1.27 \mathrm{~s}$, respectively. With the increase of pile number, the overall stiffness of pile-soil structure is larger, and the damping of pile-soil dynamic interaction increases. The antiliquefaction performance of the pile group is more conspicuous. Combined with the time history response law of pore pressure ratio, we can see the bending moment attenuation as the pore pressure ratio increases. The increase of pore water pressure ratio has a significant effect on the pile bending moment. In the increasing process of the pore water pressure ratio, the six pile bending moment declines at the earliest. The softening and damping effect of saturated silt sand before liquefaction is more obvious.

\section{Conclusions}

(1) According to the macroscopic phenomenon of shaking table test, the saturated silty sand of a single pile, four piles, and six piles all liquefied under the $0.35 \mathrm{~g}$ ground motion load. However, the liquefaction time of six piles is the most backward.

(2) The antiliquefaction performance of six piles is embodied in the pore pressure ratio, acceleration, and bending moment time history response. The average time of liquefaction of six piles is $4.62 \mathrm{~s}$ longer than that of four piles. The average time of liquefaction of four piles is 4.21 s longer than that of a single pile. The peak acceleration appearance of six piles was 3.08s later than the single pile, while the maximum bending moment appearance of six piles was $1.96 \mathrm{~s}$ later than the single pile on average.

(3) The acceleration and bending moment of the pile begins to decay at the stage of pore pressure ratio growth. The saturated silty sand liquefaction process directly results in the attenuation of pile acceleration and bending moment, which indicates that the saturated silty sand has a certain softening and damping effect before liquefaction.

(4) According to the pore pressure ratio, acceleration, and bending moment time history response law, the antiliquefaction performance of the pile group is better. The reason is that the pile group integrates the liquefaction inhibition range of a single pile. The pile groups weaken the growth rate of pore water pressure in the soil around the pile. It slowed down the accumulation of pore water pressure in the saturated silt sand around the pile, thus hindering the liquefaction of sand.

\section{Data Availability}

The data used to support the findings of this study are available from the corresponding author upon request.

\section{Conflicts of Interest}

The authors declare no conflicts of interest.

\section{Acknowledgments}

This work was supported by the Transport Department of Hainan Provincial, China (No. HNZXY2015-045R). The shaking table tests were performed at the National Center for Research in Earthquake Engineering (NCREE), and the help is highly appreciated. The authors would also like to express their great appreciation to Fengbin Yuan and Xiaoxiong Li for refining and finalizing the manuscript.

\section{References}

[1] K. Tokimatsu and Y. Asaka, "Effects of liquefaction-induced ground displacements on pile performance in the 1995 hyogoken-nambu earthquake," Soils and Foundations, vol. 38, pp. 163-177, 1998.

[2] L. Li, H. Chen, J. Li, and D. Sun, "An elastoplastic solution to undrained expansion of a cylindrical cavity in SANICLAY under plane stress condition," Computers and Geotechnics, vol. 132, no. 132, Article ID 103990, 2021.

[3] Z. J. Feng, X. Q. Wang, and X. X. Li, "Effect of sand liquefaction on mechanical properties of pile foundation under strong earthquake," Journal of Traffic and Transportation Engineering, vol. 19, no. 1, pp. 71-84, 2019.

[4] M. Gao, Y. S. Song, Y. Wang, and Q. S. Chen, "Effect of geological conditions on vibration characteristics of ground due to subway tunnel: field investigation," Geotechnical \& Geological Engineering, vol. 39, no. 6, pp. 4689-4696, 2021.

[5] H. Chen, L. Li, J. Li, and D. Sun, "A rigorous elastoplastic load-transfer model for axially loaded pile installed in saturated modified cam-clay soils," Acta Geotechnica, vol. 2021, pp. 1-17, 2021.

[6] P. Saha, K. Horikoshi, and A. Takahashi, "Performance of sheet pile as a seismic retrofit for old piled abutment subjected to liquefaction-induced lateral spreading," Soil Dynamics and Earthquake Engineering, vol. 141, no. 141, Article ID 106507, 2021.

[7] G. Gao, M. Gao, Q. Chen, and J. Yang, "Field load testing study of vertical bearing behavior of a large diameter belled cast-in-place pile," KSCE Journal of Civil Engineering, vol. 23, no. 5, pp. 2009-2016, 2019.

[8] W. Li, Y. Chen, A. W. Stuedlein, H. Liu, X. Zhang, and Y. Yang, "Performance of X-shaped and circular pile-improved ground subject to liquefaction-induced lateral spreading," Soil Dynamics and Earthquake Engineering, vol. 109, pp. 273-281, 2018. 
[9] A. Rahmani and A. Pak, "Dynamic behavior of pile foundations under cyclic loading in liquefiable soils," Computers and Geotechnics, vol. 40, pp. 114-126, 2012.

[10] W. Wu, G. Jiang, S. Huang, and C. J. Leo, "Vertical dynamic response of pile embedded in layered transversely isotropic soil," Mathematical Problems in Engineering, vol. 2014, pp. 1-12, Article ID 126916, 2014.

[11] G. Deng, J. Zhang, W. Wu, X. Shi, and F. Meng, "Soil-pile interaction in the pile vertical vibration based on fictitious soil-pile model," Journal of Applied Mathematics, vol. 2014, no. 15, 11 pages, Article ID 905194, 2014.

[12] K. Harada and J. Ohbayashi, "Development and improvement effectiveness of sand compaction pile method as a countermeasure against liquefaction," Soils and Foundations, vol. 57, no. 6, pp. 980-987, 2017.

[13] X.-L. Zhou and J.-H. Wang, "Analysis of pile groups in a poroelastic medium subjected to horizontal vibration," Computers and Geotechnics, vol. 36, no. 3, pp. 406-418, 2009.

[14] J.-F. Lu, B. Xu, and J.-H. Wang, "A numerical model for the isolation of moving-load induced vibrations by pile rows embedded in layered porous media," International Journal of Solids and Structures, vol. 46, no. 21, pp. 3771-3781, 2009.

[15] A. F. Hussein and M. H. El Naggar, "Seismic axial behaviour of pile groups in non-liquefiable and liquefiable soils," Soil Dynamics and Earthquake Engineering, vol. 149, Article ID 106853, 2021.

[16] Z. J. Feng, C. Zhang, and J. B. He, "Shaking table test of timehistory response of rock-socketed single pile under strong earthquake," Rock and Soil Mechanics, vol. 2021, no. 12, pp. 42-51, 2021.

[17] C. Xu, P. Dou, X. Du, M. H. El Naggar, M. Miyajima, and S. Chen, "Seismic performance of pile group-structure system in liquefiable and non-liquefiable soil from large-scale shake table tests," Soil Dynamics and Earthquake Engineering, vol. 138, Article ID 106299, 2020.

[18] A. Bahmanpour, I. Towhata, M. Sakr, M. Mahmoud, Y. Yamamoto, and S. Yamada, "The effect of underground columns on the mitigation of liquefaction in shaking table model experiments," Soil Dynamics and Earthquake Engineering, vol. 116, pp. 15-30, 2019.

[19] J. S. Rajeswari and R. Sarkar, "A three-dimensional investigation on performance of batter pile groups in laterally spreading ground," Soil Dynamics and Earthquake Engineering, vol. 141, no. 9, Article ID 106508, 2021.

[20] Y. Sawamura, K. Inagami, T. Nishihara, T. Kosaka, M. Hattori, and M. Kimura, "Seismic performance of group pile foundation with ground improvement during liquefaction," Soils and Foundations, vol. 61, no. 4, pp. 944-959, 2021.

[21] X. Bao, Y. Morikawa, Y. Kondo, K. Nakamura, and F. Zhang, "Shaking table test on reinforcement effect of partial ground improvement for group-pile foundation and its numericalsimulation," Soils and Foundations, vol. 52, no. 6, pp. 1043-1061, 2012.

[22] J.-S. Chiou, T.-J. Huang, C.-L. Chen, and C.-H. Chen, "Shaking table testing of two single piles of different stiffnesses subjected to liquefaction-induced lateral spreading," Engineering Geology, vol. 281, Article ID 105956, 2021.

[23] R. Wang, P. Fu, and J.-M. Zhang, "Finite element model for piles in liquefiable ground," Computers and Geotechnics, vol. 72, pp. 1-14, 2016.

[24] M. Saeedi, M. Dehestani, I. Shooshpasha, G. Ghasemi, and B. Saeedi, "Numerical analysis of pile-soil system under seismic liquefaction," Engineering Failure Analysis, vol. 94, pp. 96-108, 2018.
[25] A.-S. A. Mokhtar, M. A. Abdel-Motaal, and M. M. Wahidy, "Lateral displacement and pile instability due to soil liquefaction using numerical model," Ain Shams Engineering Journal, vol. 5, no. 4, pp. 1019-1032, 2014.

[26] A. Janalizadeh and A. Zahmatkesh, "Lateral response of pile foundations in liquefiable soils," Journal of Rock Mechanics and Geotechnical Engineering, vol. 7, no. 5, pp. 532-539, 2015.

[27] Ministry of Transport of the People's Republic of China,Specification of Seismic Design for Highway Engineering (JTGB022013), China Communications Press, Beijing, China, 2013.

[28] H. F. Sun, L. P. Jing, N. W. Wang, and X. Meng, "Development of multifunctional laminar shear container for shaking table test," Chinese Journal of Rock Mechanics and Engineering, vol. 30, no. 12, pp. 2498-2506, 2011.

[29] L. J. Yuan, X. S. Liu, X. G. Wang, Y. Yang, and Z. Yang, "Analytic solution of dynamic characteristics and responses of soil-box model for shaking table tests," Chinese Journal of Geotechnical Engineering, vol. 34, no. 6, pp. 1038-1042, 2012.

[30] K. Hamayoon, Y. Morikawa, R. Oka, and F. Zhang, "3D dynamic finite element analyses and $1 \mathrm{~g}$ shaking table tests on seismic performance of existing group-pile foundation in partially improved grounds under dry condition," Soil Dynamics and Earthquake Engineering, vol. 90, pp. 196-210, 2016.

[31] J. R. Dungca, J. Kuwano, A. Takahashi et al., "Shaking table tests on the lateral response of a pile buried in liquefied sand," Soil Dynamics and Earthquake Engineering, vol. 26, no. 2-4, pp. 287-295, 2006.

[32] Z. J. Feng, Y. X. Dong, and J. B. He, "Shaking table test of saturated fine sand liquefaction under strong earthquake," Journal of Harbin Institute of Technology, vol. 51, no. 9, pp. 186-192, 2019. 